\title{
Are Spatial Factors Important in the Adoption of Eco-Friendly Agricultural Technologies? Evidence on Integrated Pest Management (IPM)
}

\author{
Muhammad Humayun Kabir ${ }^{*}$, Ruslan Rainis², Md. Javed Azad1 \\ ${ }^{1}$ Department of Agricultural Extension and Information System, Sher-e-Bangla Agricultural University, Dhaka, Bangladesh \\ ${ }^{2}$ Department of Geography, School of Humanities, Universiti Sains Malaysia, Penang, Malaysia \\ Email: *mhumayunsau@gmail.com
}

How to cite this paper: Kabir, M.H. and Rainis, R. and Azad, Md.J. (2017) Are Spatial Factors Important in the Adoption of Eco-Friendly Agricultural Technologies? Evidence on Integrated Pest Management (IPM). Journal of Geographic Information System, 9, 98-113.

https://doi.org/10.4236/jgis.2017.92007

Received: March 6, 2017

Accepted: April 27, 2017

Published: April 30, 2017

Copyright $\odot 2017$ by authors and Scientific Research Publishing Inc. This work is licensed under the Creative Commons Attribution International License (CC BY 4.0).

http://creativecommons.org/licenses/by/4.0/

(c) $\underset{\mathrm{EY}}{0}$ Open Access

\begin{abstract}
Past studies on the adoption of integrated pest management (IPM), analyzed the significance of non-spatial factors (social, economic, institutional and management factors etc.) in influencing farmers' decision to adopt IPM while the present study analyzed spatial factors in addition to these non-spatial factors to address the questions-i. Do the spatial factors significantly influence the farmers to adopt IPM? If yes, then to what extent they do affect IPM adoption? The data were collected from 331 vegetable farmers of Narsingdi district, Bangladesh, by conducting a household survey. Farmers' nineteen characteristics under five broad groups, namely social, economic, institutional, management and spatial factors were analyzed. The result of the binary logistic regression model revealed that two spatial factors namely the distance of farmers' house from the nearest market and the distance from agriculture office, along with some specific social, economic, institutional and management factors, significantly influenced the farmers' to use IPM. It is also observed from the model that the role of spatial factors was important in influencing IPM adoption. However, with regard to the level of importance, their contribution was less than those of economic and institutional factors but more than those of social and management factors. The influences of these factors in practicing IPM are discussed individually as well as group based. The findings show significance in domestic policy making.
\end{abstract}

\section{Keywords}

Spatial Factors, Adoption, IPM, Logistic Regression Model

\section{Introduction}

In Bangladesh, the agricultural sector has made an impressive contribution over 
the last three decades in terms of food production despite the adverse condition. Food production has increased three times in 2012 from 1980 though the land use was declining by $1 \%$ per year [1] [2]. Various agricultural inputs, especially pesticides played an important role in this progress as pests (insects, pathogens, weeds etc.) are the most important threats to food production and pesticides are very effective to control pests. However, the use of chemical pesticides for controlling pests is very risky since they pollute environment by contaminating the soil, ground and surface water. Moreover, the resistance of pest, the existence of new pests and the destruction of useful insects are also the consequences of pesticide overuse. Therefore, to keep the trend of increasing food production without harming the environment, the government has promoted integrated pest management (IPM).

IPM has no fixed definition. [3] analyzed a number of definitions of IPM and commented that environmental safety is the focus of all the given definitions. In general IPM is an approach where pests are controlled by following a number of technologies that can be categorized as mechanical control, cultural, biological, chemical control etc. The technologies or practices used in IPM are environmentally friendly. In this approach, chemicals are only used when there is no alternative or when the pest infestation exceeds economic threshold level. Since the farmers who adopted IPM prefer to control pest by applying some technologies which are non-chemicals thus they can reduce the use of pesticides. Furthermore, through the successful application of IPM technologies, farmers can ensure to obtain the desired yield. Due to these advantages, IPM is getting popular day by day as a better alternative for both developed and developing countries.

On the realization of the need of IPM in Bangladesh, the government with the assistance of FAO had launched IPM program for vegetables farmers more than one decade ago. From that period, the Department of Agricultural Extension (DAE), the prime and largest agricultural organization, with the support of various non-government organizations (NGO), international agencies and development banks, has disseminated information on IPM [4] [5]. The goal of this effort is to promote the adoption of IPM by vegetable farmers. Though the government, with the help of various organizations, has been trying to increase the adoption of IPM, but how do farmers make their decision or what are the factors that influence their decision to adopt this eco-friendly approach is not studied.

Studies have been conducted to justify the profitability of IPM and the effectiveness of IPM dissemination techniques in Bangladesh [6] [7] [8] [9] [10]. These studies have attempted to justify whether IPM is profitable or not and they have identified the most effective IPM dissemination techniques. However, they have yet to explore the factors that influence farmers to decide to adopt IPM. On the other hand, studies on determinants of the adoption of IPM have been conducted in different countries. The results showed that IPM adoption is usually influenced by various social, economic, institutional, and management factors [11]-[16]. However, the results of those studies varied across the countries. Moreover, those studies generally overlooked spatial factors that are be- 
lieved to affect agricultural technology adoption [17] [18] [19] [20]. As the adoption is complex and related to various factors, it is therefore necessary to conduct a study with farmers' spatial characteristics besides others. By considering this fact, the study attempted to identify the factors that have important impact on vegetable farmers' use of IPM. Five broad types of factors such as social, economic, institutional, management and spatial were examined in the study. Since spatial factors were considered as a new dimension, thus this study examined not only they are important or not but also make a comparison between their importances with others. Therefore, the objectives of the study are to identify the factors that significantly influence vegetable farmers' IPM adoption and to assess the spatial factors influence in the adoption of IPM.

\section{Theoretical Background}

\subsection{Adoption of IPM}

Adoption is "the mental process an individual passes from first hearing about an innovation to final adoption" [21]. This indicates that adoption is not an instantaneous act rather a process that occurs over time. Farmers may not accept an innovation immediately after hears; they need time for thinking over things to reach a final decision. In this time period they pass several stages. According to Rogers, to take decision about an innovation individual as decision maker passes through in five stages namely: knowledge, persuasion, decision, implementation and confirmation. Like any innovation, to adopt IPM, the farmers also go through these stages. However, they are influenced by a number of factors in each stage. Therefore, it can be said that farmers adoption decision is related with various factors.

\subsection{Factors Influencing the Adoption of IPM}

The decision to adopt any innovation is influenced by the information receivers' socio-economic characteristics, the role of change agents or diffusion methods and the characteristics of the innovation [22]. Numerous empirical studies on adoption of agricultural technologies including IPM have corroborated this concept. From his concept as well as previous studies, the factors that have been found to influence growers' decision to adopt agricultural technology including IPM can be categorized into four broad items such as social, economic, institutional and management. The study will consider all these broad categories as well as a new dimension like spatial factors. This is because though spatial factors are not analyzed in adoption of IPM but their influence is studied in case of other agricultural technologies and found significant affect. Therefore, the study will analyze what social, economic, institutional, management and spatial factors influence vegetable growers' adoption of IPM (Figure 1).

\subsection{Spatial Factors Influence in the Adoption of Agricultural Technologies}

The influence of spatial factors were analyzed on various agricultural technologies 


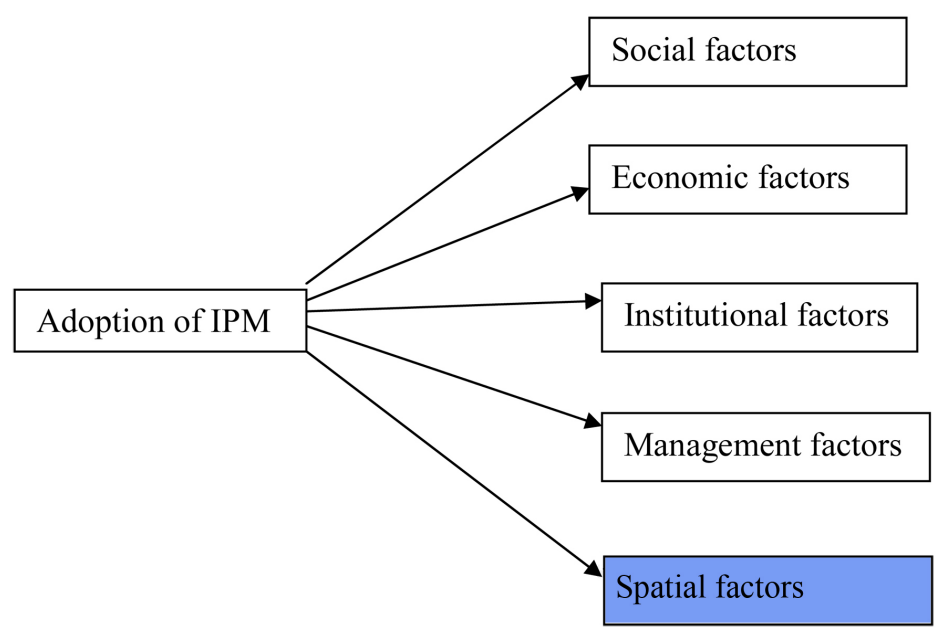

Figure 1. Conceptual framework for factors influencing adoption of IPM (Blue shaded indicates the new dimensions).

such as agricultural intensification, organic farming, fertilizer, herbicide, integrated crop nutrient management, improved verity, soil conservation, integrated rice fish farming, land management, crop rotation, tillage etc. (Table 1). Among these technologies, some are single in nature while others are as a set of practices like IPM. Table 1 show that a variety of spatial factors were analyzed on different agricultural technology adoption studies and found a mixed result. In most cases, the impact was statistically significant which implies the importance of spatial factors in technology adoption decision. However, these studies focused on various technologies rather than on IPM. In addition to this, these studies only tested whether the spatial factors were significant or not in farmers adoption decision. The current study attempted to analyze the spatial factors, not only to know whether they are important (significant) or not in the adoption of IPM but also their level of importance.

\section{Materials and Methods}

Structured questionnaire and Global Positioning System (GPS) were used to collect data from the farmers of Narsingdi district, an intensive vegetable growing region of Bangladesh. By following a multistage sampling technique, twelve villages in Belabo upazila (sub-district) of Narsingdi district were selected for the survey. These villages were selected based on vegetable cultivation intensity, frequency of pesticide application and the existence of IPM program. A total number of 1926 vegetable farmers of the selected villages were obtained from the respective upazila agriculture office considered as population of the study. By considering time and other resources, a total of 331 vegetable farmers were selected as sample, comprising $17 \%$ from the total population. These farmers were selected randomly for the interview.

The vegetable farmers nineteen characteristics under five broad categories namely; social, economic, institutional, management and spatial were considered in the study. An in-depth interview based on structured questionnaire was held 
Table 1. Spatial factors influence in various agricultural technology adoption.

\begin{tabular}{|c|c|c|c|c|}
\hline Author & Study location & Name of factor & Name of technology & Output \\
\hline$[17]$ & Nepal & $\begin{array}{c}\text { Distance to fertilizer store, } \\
\text { Distance to plot }\end{array}$ & $\begin{array}{l}\text { Agricultural } \\
\text { intensification }\end{array}$ & $\begin{array}{l}\text {-ve and significant } \\
\text { +ve and non-significant }\end{array}$ \\
\hline$[23][24]$ & Cameroon, Honduras & $\begin{array}{c}\text { Distance of field from home, } \\
\text { Distance to city }\end{array}$ & Organic agriculture & $\begin{array}{c}\text {-ve and significant } \\
\text {-ve and non-significant }\end{array}$ \\
\hline$[25]$ & Ethiopia & $\begin{array}{l}\text { Distance from farm } \\
\text { to the market }\end{array}$ & Herbicide & +ve and significant \\
\hline$[25][26][27]$ & $\begin{array}{l}\text { Malawi, } \\
\text { Ethiopia, Mozambique }\end{array}$ & $\begin{array}{l}\text { Distance of the plot } \\
\text { from the market }\end{array}$ & Fertilizer & $\begin{array}{l}\text {-ve and significant } \\
\text { +ve and significant }\end{array}$ \\
\hline$[28][29]$ & Nigeria, Bangladesh & $\begin{array}{l}\text { Distance to source of } \\
\text { technology, Distance to } \\
\text { market, Distance to } \\
\text { rice mill and agri. office }\end{array}$ & Improve variety & $\begin{array}{l}\text {-ve and significant } \\
\text {-ve and non-significant }\end{array}$ \\
\hline$[18][30]$ & Philippines, Indonesia & $\begin{array}{l}\text { Distance to market, Distance } \\
\text { to information source } \\
\text { and meeting place }\end{array}$ & $\begin{array}{l}\text { Integrated crop } \\
\text { management }\end{array}$ & $\begin{array}{c}\text { +ve and significant } \\
\text {-ve and non-significant } \\
\text {-ve and significant }\end{array}$ \\
\hline$[31][32]$ & Ethiopia, Uganda & Distance to farm from home & Soil conservation & -ve and significant \\
\hline$[33]$ & Ethiopia & $\begin{array}{l}\text { Distance to farm plot } \\
\text { from home }\end{array}$ & Land management & -ve and significant \\
\hline$[34]$ & Bangladesh & $\begin{array}{l}\text { Mean distance of farm } \\
\text { plot from household }\end{array}$ & $\begin{array}{c}\text { Integrated } \\
\text { rice-fish farming }\end{array}$ & Non-significant \\
\hline$[35]$ & Ethiopia & $\begin{array}{l}\text { Distance to farm plot, } \\
\text { Distance to market }\end{array}$ & Crop rotation & -ve and non-significant \\
\hline$[20]$ & Ethiopia & $\begin{array}{l}\text { Distance to market and } \\
\text { road, Distance to input } \\
\text { and credit office, } \\
\text { Distance to agriculture office }\end{array}$ & Improved forages & $\begin{array}{l}\text { +ve and significant } \\
\text {-ve and significant } \\
\text { +ve and non-significant }\end{array}$ \\
\hline$[27]$ & Mozambique & Distance to the market & Mechanization & -ve and non-significant \\
\hline$[27]$ & Mozambique & Distance to the market & Animal traction & +ve and significant \\
\hline$[23]$ & Cameroon & Distance from home to field & $\begin{array}{c}\text { Integrated soil } \\
\text { nutrient management }\end{array}$ & -ve and significant \\
\hline$[36]$ & Nigeria & $\begin{array}{l}\text { Distance of farmland } \\
\text { to farmers home }\end{array}$ & $\begin{array}{l}\text { Improve cassava } \\
\text { production }\end{array}$ & -ve and non-significant \\
\hline$[18]$ & Philippines & Distance to nearest market & Certified seed & -ve and non-significant \\
\hline$[37][27]$ & $\begin{array}{l}\text { Cameroon, } \\
\text { Mozambique }\end{array}$ & $\begin{array}{c}\text { Distance to field from } \\
\text { homestead, Distance to market }\end{array}$ & Pesticide & $\begin{array}{l}\text { +ve and non-significant } \\
\text {-ve and non-significant }\end{array}$ \\
\hline
\end{tabular}

with the sample farmers to collect the data related to non-spatial factors or characteristics. The questionnaire was divided into four parts. The first part was related to farmers' social characteristics measured by the variables of age, education, household size and perception towards IPM. The second part highlighted farmers' economic characteristics in terms of the variables such as farm size, area 
under vegetable cultivation, annual income and land ownership status. The third part evaluated farmers' participation towards institutional support like farmer field school training, contact with extension agent, field day demonstration and membership of IPM club. The fourth and last part measured some of the farmers managerial activities such as the use of improved variety, time spent on the farm per day and the number or type of vegetable grown in a year. On the other hand, spatial data were collected by using a handheld GPS. GPS coordinates were recorded from each of the survey respondent's place of residence and four key locations such as upazila agriculture office, nearest market, pesticide store and national highway (Figure 2). Later by using Arc GIS (version 9.3) software, the distance between the farmers' house and these four focal points were measured.

The farmers' nineteen characteristics were treated as independent variables or predictors in the study. Some of these are binary while others are continuous. The dependent variable adoption of IPM is binary in nature. The type and

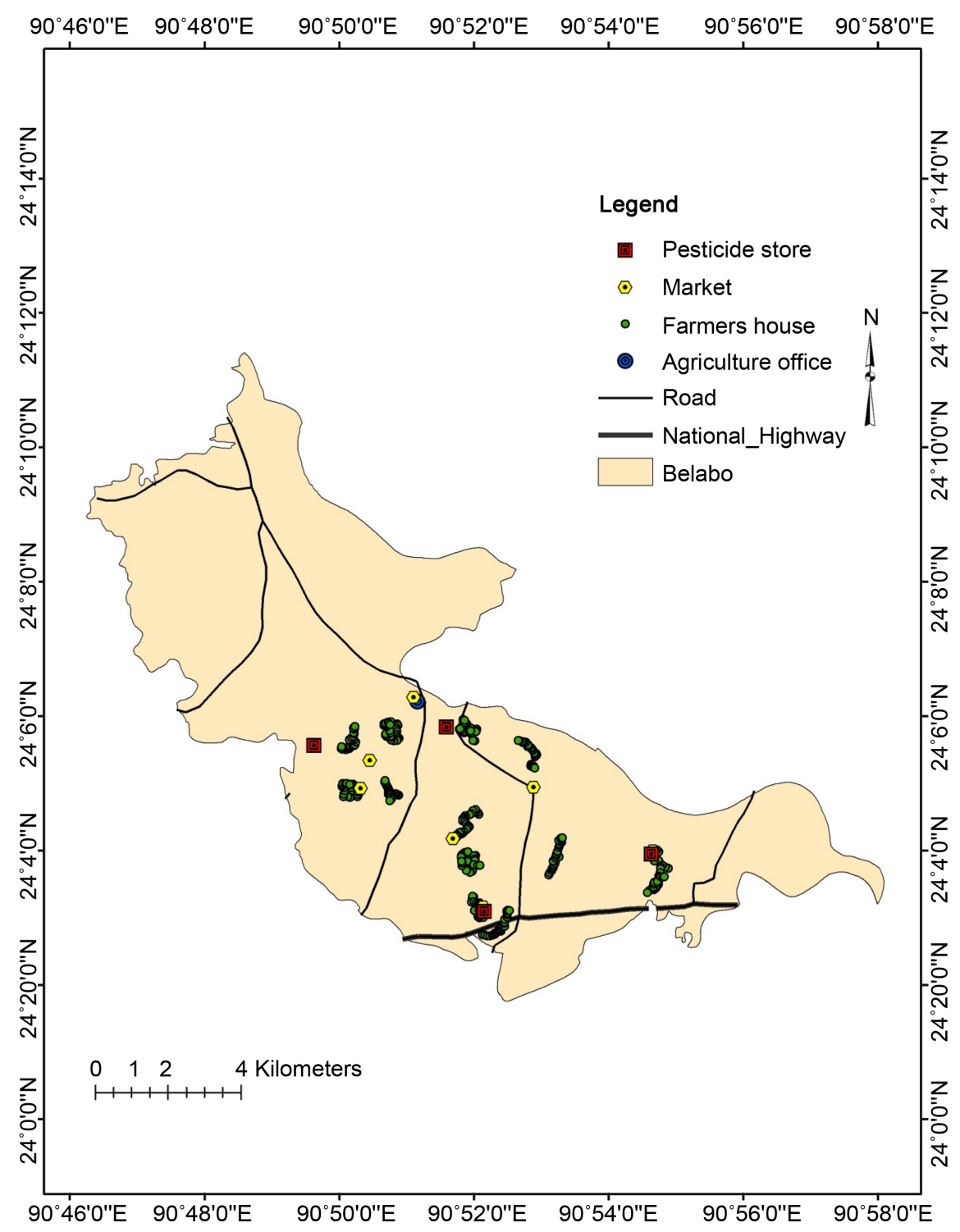


Figure 2. Map of Belabo upazila, Narsingdi district, Bangladesh showing vegetable growers' house and four key locations (agriculture office, market, pesticide store and highway). measuring techniques of both independent and dependent variable are presented in Table 2. As the dependent variable may have any one option of the two; either the adoption or rejection, then to justify the impact of independent variables on IPM adoption, binary logistic regression model is considered the most appropriate [17] [23]. The model was applied in the study twice. In the first stage, as independent variables, social, economic, institutional and management factors were considered. In the second stage, spatial factors in addition to these were entered. That means the difference between two stages of the logistic regression model is spatial factors where in the first stage these factors are absent and present in the second stage. This was done for better understanding about the effect of spatial factors in the adoption of IPM.

Prior to entering the independent variables into the model, they were checked to identify the colinearity problem. In the first stage, there was no colinearity among the independent variables. As a result all (15) factors were entered in the model. In the second stage, the independent variable (distance of the farmers' house to national highway) was excluded from the model as it shows a high degree of correlation with another independent variable (distance to agriculture office) and a low degree of correlation with dependent variable. Therefore, eighteen independent variables were finally considered to be included into the second stage of the model.

\section{Results}

\subsection{Important Factors in IPM Adoption}

The first step of the binary logistic regression model was applied to identify the social, economic, institutional and management factors that significantly influence vegetable farmers to adopt IPM. The $-2 \log$ likelihood value indicates that the data were well fitted for the model. The result of omnibus test of model chi-square is also reinforced the findings. Nagelkarke $r^{2}$ value is 0.591 which denotes the independent variables explained the model 59\%. The model correctly predicted about $86 \%$ of the variation in the adoption behavior for the sample farmers.

The model showed 5 variables out of 15 were statistically significant determinants (Table 3 ). These are perception towards IPM, land ownership status, frequency of extension contact, farmer field school training program and use of improved variety. Among these variables, perception towards IPM, frequency of contact with extension agent and use of improved variety were significant at the $1 \%$ level of confidence while others showed significance at the $0.1 \%$ level. However, all these variables showed a positive relationship with farmers IPM adoption behavior which indicates the higher these variables the higher the probability of IPM adoption.

\subsection{Influence of Spatial Factors in IPM Adoption}


In order to assess the influence of spatial factors, the study again used logistic regression model. In this step, besides social, economic, institutional and manTable 2. Description of the variables used in the analysis.

\begin{tabular}{|c|c|c|}
\hline Variables name & Type & Description \\
\hline \multicolumn{3}{|l|}{ Dependent variable } \\
\hline $\begin{array}{c}\text { ADOPTIPM } \\
\text { (Adoption of IPM) }\end{array}$ & Binary & If farmers adopt IPM practice $[1=\mathrm{Yes}, 0=\mathrm{No}]$ \\
\hline \multicolumn{3}{|c|}{ Independent variables } \\
\hline \multicolumn{3}{|l|}{ Social factors } \\
\hline AGE & Continuous & Age of the vegetable farmers head (years) \\
\hline EDUCATION & Continuous & Number of years of formal schooling (years) \\
\hline HOSIZE & Binary & Number of household members (person) \\
\hline PERCEPTION & Binary & $\begin{array}{l}\text { If farmers have a favorable perception towards IPM } \\
\qquad[1=\text { Yes, } 0=\text { No }]\end{array}$ \\
\hline \multicolumn{3}{|l|}{ Economic factors } \\
\hline FARMSIZE & Continuous & Total farm size (ha) \\
\hline VEGAREA & Continuous & $\begin{array}{l}\text { Out of total farm size, the area which is used for } \\
\text { vegetable cultivation (\%) }\end{array}$ \\
\hline INCOME & Continuous & $\begin{array}{l}\text { Amount of money earned by the family members in } \\
\text { a year ('000 BDT) }\end{array}$ \\
\hline LANDOWN & Binary & $\begin{array}{l}\text { If farmers cultivate his own land } \\
\qquad[1=\text { Yes, } 0=\mathrm{No}]\end{array}$ \\
\hline \multicolumn{3}{|l|}{ Institutional factors } \\
\hline EXCONT & Continuous & $\begin{array}{l}\text { Number of contact by the farmers with the } \\
\text { extension agent in a crop season }\end{array}$ \\
\hline FFS & Binary & $\begin{array}{l}\text { If farmers participate in FFS training program } \\
\qquad[1=\text { Yes, } 0=\mathrm{No}]\end{array}$ \\
\hline FLDAY & Binary & $\begin{array}{l}\text { If farmers participate in field day demonstration } \\
\qquad[1=\text { Yes, } 0=\mathrm{No}]\end{array}$ \\
\hline MEMBIPM & Binary & $\begin{array}{l}\text { If farmers are member of an IPM club } \\
\qquad[1=\text { Yes, } 0=\mathrm{No}]\end{array}$ \\
\hline \multicolumn{3}{|l|}{ Management factors } \\
\hline FARMHOUR & Continuous & Time spent in farm per day (hours) \\
\hline VARIETY & Binary & If farmers use improved variety $[1=$ Yes, $0=$ No] \\
\hline VEGETBNO & Continuous & Type or no of vegetable grown \\
\hline \multicolumn{3}{|l|}{ Spatial factors } \\
\hline DISAGOF & Continuous & Distance of farm house to agriculture office $(\mathrm{Km})$ \\
\hline DISHWAY & Continuous & Distance of farm house to national highway $(\mathrm{Km})$ \\
\hline DISMARK & Continuous & Distance of farm house to nearest market $(\mathrm{Km})$ \\
\hline DISPEST & Continuous & $\begin{array}{l}\text { Distance of farm house to nearest pesticide store } \\
\qquad(\mathrm{Km})\end{array}$ \\
\hline
\end{tabular}

agement factors, spatial factors were considered for analyze. The reasons behind consider all the factors in this step is to assess the influence of spatial factors in 
the adoption of IPM as well as to make a comparison between their level of influence with others. The $-2 \log$ likelihood value and other parameters indicate that still the model is valid. Moreover, by adding spatial factors, the validity of the model has increased.

In the second step, the logistic regression model explored seven variables that significantly affect the vegetable farmers to adopt IPM (Table 4). These are perception towards IPM, land ownership status, frequency of extension contact, farmer field school training, distance from farmers house to agricultural office, distance from farmers house to the nearest market and use of improved variety. Therefore, the second step of the model explored an increase number of significant factors. Two spatial factors out of four namely distance of farmers house to agricultural office and distance of farmers house to the nearest showed significant impact on the adoption of IPM.

However, the variables that had significant effect on practicing IPM were not same in terms of the level of significance. To compare among them regarding the level of importance, the study used p value (significance) and wald stat as these two parameters indicate how strong the level of significance of an independent variable with the dependent variable [17] [24]. The wald statistics and $p$ value of the significant variables are presented in Table 5. From the table, it was observed that institutional factors were the most important contributors followed by economic, spatial, social and management factors. Alternatively it can be said that the importance of spatial factors in the adoption of IPM was lower than those of economic and institutional factors but higher than those of social

Table 3. Summary statistics of the first stage of logistic regression model.

\begin{tabular}{cccccc}
\hline Variables & $\beta$ & S. E & Wald & Sig & Exp $(\beta)$ \\
\hline Perception towards IPM & $2.601^{\star}$ & 0.795 & 10.704 & 0.001 & 13.475 \\
Land ownership status & $2.587^{\star *}$ & 0.515 & 25.254 & 0.000 & 13.294 \\
Frequency of extension contact & $0.177^{\star}$ & 0.059 & 8.976 & 0.003 & 1.194 \\
Farmers field school training & $2.434^{\star *}$ & 0.423 & 33.055 & 0.000 & 11.402 \\
Use of improved variety & $1.235^{\star}$ & 0.386 & 10.258 & 0.001 & 3.438 \\
\hline
\end{tabular}

$-2 \log$ likelihood $=226.605$. Omnibus test of model Chi-square value $=10.187(\mathrm{P}<0.01)$. Nagelkarke $\mathrm{r}^{2}=$ 0.591 . Overall percentage of correct prediction $=85.8 .^{*}=$ Correlation is significant at the 0.01 level. ${ }^{*}=$ Correlation is significant at the 0.001 level.

Table 4. Summary statistics of the second stage of logistic regression model.

\begin{tabular}{cccccc}
\hline Variables & $\beta$ & S. E & Wald & Sig & Exp $(\beta)$ \\
\hline Perception towards IPM & $2.815^{* *}$ & 0.812 & 12.017 & 0.001 & 16.689 \\
Land ownership status & $2.876^{* * *}$ & 0.559 & 26.501 & 0.000 & 17.737 \\
Frequency of extension contact & $0.196^{* *}$ & 0.062 & 9.794 & 0.002 & 1.216 \\
Farmer field school & $2.645^{* * *}$ & 0.453 & 34.173 & 0.000 & 14.087 \\
Distance to agricultural office & $-0.188^{*}$ & 0.083 & 5.172 & 0.023 & 0.829 \\
Distance to the nearest market & $1.521^{\star * *}$ & 0.420 & 13.134 & 0.000 & 4.577 \\
Use of improved variety & $1.300^{* *}$ & 0.407 & 10.220 & 0.001 & 3.668 \\
\hline
\end{tabular}


-2 Log likelihood $=206.990$. Omnibus test of model chi-square value $=5.379(\mathrm{P}<0.05)$. Nagelkarke $\mathrm{r}^{2}=$ 0.639. Overall percentage of correct prediction $=86.7{ }^{*}=$ Correlation is significant at the 0.05 level. ${ }^{* *}=$ Correlation is significant at the 0.01 level. ${ }^{* *}=$ Correlation is significant at the 0.001 level.

Table 5. The logistic regression model showing wald stat and $\mathrm{p}$ value (significance) of the significant factors of IPM adoption.

\begin{tabular}{cccc}
\hline Type of factors & Name of factors & Wald stat & Significance (p value) \\
\hline Social & Perception towards IPM & 12.017 & 0.001 \\
Economic & Land ownership status & 26.501 & 0.000 \\
& Farmers field school & 34.173 & 0.000 \\
Institutional & Extension contact & 9.794 & 0.002 \\
\multirow{2}{*}{ Management } & Use of improved variety & 10.220 & 0.001 \\
\multirow{2}{*}{ Spatial } & Distance to the nearest market & 13.134 & 0.000 \\
& Distance to agriculture office & 5.172 & 0.023 \\
\hline
\end{tabular}

and management factors.

\section{Discussion}

The effort of the government to disseminate IPM practices will be meaningless if a major portion of the farmers do not adopt these. The study observed that fewer farmers' (30\%) adopted these environmentally friendly farming practices. It is important to understand farmers' specific characteristics before disseminating any innovation at farm level. The study had made an attempt to identify the factors that influence vegetable farmer's adoption behavior of IPM. The findings of the study explored that farmers' adoption behavior is influenced by some specific social, economic, institutional, management and spatial characteristics. Under institutional characteristics, the participation in farmer field school (FFS) training program and the frequency of extension contact were significant and positively influenced the vegetable farmers to practice IPM. As using IPM is a technical job, farmers who participated in the FFS training program and who made contact with local extension agent gained more knowledge and skill about IPM. That is why these two institutional supports motivated them more to use IPM technologies than those who were deprived from these facilities. The findings of this study are similar with those revealed by [38] and [39] who asserted that information seeking behavior, such as extension contact or training, are helpful to motivate farmers to adopt sustainable agricultural practices.

Among several social and economic characteristics, the influence of land ownership status and perception towards IPM were important for vegetable farmers to adopt environmentally friendly crop protection practices. The farmers who cultivated their own land and had favorable perception were more inclined to use IPM practices than those who were tenants and had unfavorable perception. Tenant farmers always try to achieve a high profit as they own the land instead of having attracted amount of money. Therefore, they feel that it is a risk to employ new practices. Moreover, they are less interested to adopt IPM when they observed that a major portion of the farmers are not adopting IPM. The farmers who cultivated other land were less interested to cultivate vegetables 
using the new system [40]. On the other hand, farmers who had unfavorable perception towards IPM were less likely to practice this which is consistent with what [24] affirmed that farmers adopted organic practices as they thought the practices are environmentally sound. Alike these socio-economic characteristics, the use of improved variety had a significant and positive relationship with farmers IPM adoption behavior. This denotes that farmers who used improved variety were more interested to adopt IPM than those who used local variety. The task of collecting improved vegetable variety by the farmers in the study area was not easy. It is logical to assume that the farmers who used improved variety were more extrovert or innovative than those who used local variety. These characteristics may have more influence on improved variety users to cultivate vegetables using environmentally sound technologies such as IPM.

Moreover, the results of the study also showed two spatial dimensions, namely the distance of farmers' house from the nearest market and the distance from agriculture office that were significantly related with farmers IPM adoption behavior. The positive sign of the co-efficient of distance to the market indicated that the vegetable farmers who lived close to the market were less interested to adopt IPM than those who stayed far way. The finding is contrary to what one would generally expect. However, [18] found positive relation between market distance and adoption of integrated crop management technologies. The probable explanation of getting positive sign in the study is that the farmers who stayed close to the market may have more distraction from vegetable farming as they might be spending more time in non-agricultural activities. Moreover, these farmers might think that whatever they produce can be easily sold with very little or no transportation cost. This implies the necessity to arrange meeting or informal discussion with the farmers who stay close to the market in order to make them more aware of the beneficial use of IPM practices.

Another spatial dimension discovered to be also important in logistic regression analysis was farmers' home distance from the agricultural office. The negative direction indicates that farmers whose houses were close to agriculture office were more likely to adopt IPM than those who comparatively stayed far away. The result is quite rational as agriculture office plays the role of information centre. The office is also used as a place for conducting training and holding agricultural fair besides departmental activities. Thus, the farmers who stayed within surroundings of the office can easily and quickly obtain information regarding IPM. The respective officers would also allow them to have discussion regarding the use of IPM which was comparatively difficult for those who stayed far away.

The contribution of spatial factors was higher than social and management factors but lower than economic and institutional factors. The finding is logical. There were continuous studies on determinants of IPM adoption since more than three decades. During this long period, it is very difficult to find a study which does not focused on economic and institutional factors to discover their importance. That is why it can be said that the significance of these factors in the 
adoption of IPM is well established. A new dimension like spatial factor may less important than these factors. In fact the spatial factor plays a more important role than social and management factors which were considered by several studies.

The contribution of institutional factors was the highest in influencing vegetable farmers' decision to adopt IPM. In Bangladesh, DAE developed some approaches such as farmer field school training program, field day demonstration, movement of extension agent and establishment of IPM club for disseminating and implementing IPM technologies. Besides, the organization used mass media (electronic and print) to speed up these activities. This study considered all the above mentioned approaches except for the mass media. The reason is that farmers used some electronic media such as Radio and Television for their recreational purposes not as a learning tool to improve their agricultural technology. Besides, due to their low educational level and purchasing ability, they were less interested to obtain information from the print media (newspaper, magazine, bulletin, leaflet etc.). Out of four institutional factors, farmer field school and extension agent are the two significant factors that helped to ascertain that institutional factors are the most important for IPM adoption. The result is compatible with those of other studies such as conducted by [18] [41] [42] and [43] who found institutional factors to have the biggest impact on agricultural technology adoption. On the other hand, management factors were the least important in adoption of IPM which is consistent with the findings of [15] and [44].

Individual characteristics that were significant covered all five broad categories. According to the level of importance of the independent variables, contribution of spatial factors was lower than those of economic and institutional factors but higher than those of social and management factors. The notable matter is that the spatial factor, which was taken as new dimension in the study, was found as not only important but also the $3^{\text {rd }}$ most important contributor in the adoption of IPM. Hence, the spatial factors should be given emphasize by the policy makers in order to increase the adoption of this ecological sound approach (IPM).

\section{Conclusion}

Studies on determinants of adoption of IPM during the last three decades explored various social, economic, institutional and management factors as important determinants. This study analyzed spatial factors, besides others, to identify the important factors for vegetable farmers adoption of IPM by taking the issue of adoption behavior is complex and related with assorted factors. In addition, the study discussed the importance of the factors according to their categories besides individually. Regarding the first issue, it was observed through statistical analysis that farmers' IPM adoption decision was influenced by various spatial, social, economic, institutional and management factors such as FFS training, extension contact, land ownership, perception towards IPM, distance to nearest market, use of improved variety and distance to agriculture office. So, in 
order to increase the adopters of IPM, DAE should take the initiative to facilitate more FFS training and extension contact for the farmers. Moreover, during the selection session of farmer for training program and for extension contact, emphasize should be given to those who are tenant farmers, who have unfavorable perception towards IPM and use local variety, who live close to the market but far away from agriculture office as these farmers show less interest to adopt IPM. Regarding the second issue, it was discovered that the importance of spatial factors in the adoption of IPM was higher than those of social and management factors but lower than those of economic and institutional factors. Though there were variations among the significant factors regarding their level of contribution, for policy making, all significant factors should be considered in order to improve the adoption rate of IPM. However, in case of fund, time and other limitations focus can be concentrated on the few top most important factors. Many factors are relevant with the technology adoption but only twenty characteristics were selected for investigation in this study. Moreover, the study is conducted in a specific location of Bangladesh. Therefore, study should conduct with considering various factors giving emphasize on spatial items and a different location.

\section{Acknowledgements}

We are grateful to TWAS-USM (The academy of sciences for the developing world and Universiti Sains Malaysia, Penang, Malaysia) Post Graduate Fellowship for financial assistance for this study.

\section{References}

[1] Kabir, M.H. and Rainis, R. (2013) Sustainable Development Strategies and Challenges for Promotion of Integrated Pest Management Program in Bangladesh Agriculture. American-Eurasian Journal of Agricultural and Environmental Sciences, 13, 988-995.

[2] Kabir, M.H. and Rainis, R. (2012) Farmers' Perception on the Adverse Effects of Pesticide on Environment: A Case of Bangladesh. International Journal of Sustainable Agriculture, 4, 25-32.

[3] Lynch, S., Green, C. and Carol, K. (1996) Broadening support for 21st century IPM. Proceedings of the 3rd National IPM Symposium/Workshop: Broadening Support for 21 st Century IPM, Washington DC, 27 February-1 March 1996.

[4] DAE (2012) IPM Phase-II, Plant Protection Wing of Department of Agricultural Extension, Farmgate, Dhaka, Bangladesh.

[5] Kabir, M.H. and Rainis, R. (2013b) Integrated Pest Management Farming in Bangladesh: Present Scenario and Future Prospect. Journal of Agricultural Technology, 9, 515-527.

[6] Nasrin, M.F. (2010) Prospects of Integrated Pest Management in Bangladesh. Paper Presented in a Workshop on IPM in Bangladesh, Dhaka, Bangladesh.

[7] FPMU (2012) Food Planning and Monitoring Unit. Ministry of Food and Disaster Management of the Government of Bangladesh.

[8] Dasgupta, S., Meisner, C. and Wheeler, D. (2007) Is Environmentally Friendly Agriculture Less Profitable for Farmers? Evidence on Integrated Pest Management 
in Bangladesh. Applied Economic Perspectives and Policy, 29, 103-118.

[9] Harris, L.M. (2011) Modeling a Cost-Effective IPM Dissemination Strategy for Vegetables and Rice: An Example in South Asia. MSc Thesis, Virginia Polytechnic Institute and State University, Blacksburg.

[10] Ricker-Gilbert, J. (2005) Cost-Effectiveness Evaluation of Integrated Pest Management (IPM) Extension Methods and Programs: The Case of Bangladesh. MSc Thesis, Virginia Polytechnic Institute and State University, Blacksburg.

[11] Samiee, A., Rezvanfar, A. and Faham, E. (2009) Factors Influencing the Adoption of Integrated Pest Management (IPM) by Wheat Farmers in Varamin County, Iran. African Journal of Agricultural Research, 4, 491-497.

[12] Singh, A., Vasishtb, A.K., Kumar, R. and Das, D.K. (2008) Adoption of Integrated Pest Management Practices in Paddy and Cotton: A Case Study in Haryana and Punjab. Agricultural Economics Research Review, 21, 221-226.

[13] Chaves, B. and Riley, J. (2001) Determination of Factors Influencing Integrated Pest Management Adoption in Coffee Berry Borer in Colombian Farms. Agriculture, Ecosystems and Environment, 87, 159-177.

[14] Ofuoku, A.U., Egho, E.O. and Enujeke, E.C. (2008) Integrated Pest Management (IPM) Adoption among Farmers in Central Agro-Ecological Zone of Delta State, Nigeria. African Journal of Agricultural Research, 3, 852-856.

[15] Bonabana-Wabbi, J., Taylor, D.B. and Kasenge, V. (2006) A Limited Dependent Variable Analysis of Integrated Pest Management Adoption in Uganda. Paper Presented at the American Agricultural Economics Association Annual Meeting, Long Beach.

[16] Kabir, M.H. and Rainis, R. (2013c) Determinants and Methods of Integrated Pest Management Adoption in Bangladesh: An Environment Friendly Approach. American-Eurasian Journal of Sustainable Agriculture, 7, 99-107.

[17] Raut, N., K Sitaula, B., Vatn, A. and Paudel, G. (2011) Determinants of Adoption and Extent of Agricultural Intensification in the Central Mid-Hills of Nepal. Journal of Sustainable Development, 4, 47-60. https://doi.org/10.5539/jsd.v4n4p47

[18] Mariano, M.J., Villano, R. and Fleming, E. (2012) Factors Influencing Farmers' Adoption of Modern Rice Technologies and Good Management Practices in the Philippines. Agricultural System, 110, 41-53.

[19] Todo, Y., Yadate, D.M., Matous, P. and Takahashi, R. (2011) Effects of Geography and Social Networks on Diffusion and Adoption of Agricultural Technology: Evidence from Rural Ethiopia. Kyoto University, Kyoto.

[20] Beshir, H. (2014) Factors Affecting the Adoption and Intensity of Use of Improved Forages in North East Highlands of Ethiopia. American Journal of Experimental Agriculture, 4, 12-27. https://doi.org/10.9734/AJEA/2014/5481

[21] Rogers, E.M. (1995) Diffusion of Innovations. 4th Edition, The Free Press, New York.

[22] Rogers, E.M. (2003) Diffusion of Innovations. 5th Edition, The Free Press, New York.

[23] Nkamleu, G.B. (2007) Modeling Farmers' Decisions on Integrated Soil Nutrient Management in Sub-Saharan Africa: A Multinomial Logit Analysis in Cameroon. In: Bationo, A., Ed., Advances in Integrated Soil Fertility Management in Sub-Saharan Africa: Challenges and Opportunities, Springer, Berlin, 891-903. https://doi.org/10.1007/978-1-4020-5760-1_85

[24] Wollni, M. and Andersson, C. (2013) Spatial Patterns of Organic Agriculture Adoption: Evidence from Honduras. Global Food Discussion Paper No. 20, 
George-August University of Gottingen, Gottingen.

[25] Dadi, L., Burton, M. and Ozanne, A. (2001) Adoption and Intensity of Fertilizer and Herbicide Use in the Central Highlands of Ethiopia, Agrekon. Agricultural Economics Research, Policy and Practice in Southern Africa, 40, 316-333.

[26] Chirwa, E.W. (2005) Adoption of Fertilizer and Hybrid Seeds by Smallholder Maize Farmers in Southern Malawi. Development Southern Africa, 22, 1-12. https://doi.org/10.1080/03768350500044065

[27] Uaiene, R.N., Arndt, C. and Masters, W.A. (2009) Determinants of Agricultural Technology Adoption in Mozambique. Discussion Paper No. 67E, Ministry of Planning and Development, Republic of Mozambique, Tete.

[28] Idrisa, Y.L., Ogunbameru, B.O. and Madukwe, M.C. (2012) Logit and Tobit Analyses of the Determinants of Likelihood of Adoption and Extent of Adoption of Improved Soya Bean seed in Borno State, Nigeria. Greener Journal of Agricultural Sciences, 2, 37-45. https://doi.org/10.15580/GJAS.2013.3.1231

[29] Holloway, G., Shankar, B. and Rahman, S. (2002) Bayesian Spatial Probit Estimation: A Primer and an Application to HYV Rice Adoption. Agricultural Economics, 27, 383-402. https://doi.org/10.1111/j.1574-0862.2002.tb00127.x

[30] Kariyasa, K. and Dewi, Y.A. (2013) Analysis of Factors Affecting Adoption of Integrated Crop Management Farmer Field School Estimation: (Icm-Ffs) in Swampy Areas. International Journal of Food and Agricultural Economics, 1, 29-38.

[31] Fentie, D., Fufa, B. and Bekele, W. (2013) Determinants of the Use of Soil Conservation Technologies by Smallholder Farmers: The Case of Hulet Eju Enesie District, East Gojjam Zone, Ethiopia. Asian Journal of Agriculture and Food Sciences, 1, 119-138.

[32] Barungi, M., Ng'ong'ola, D.H., Edriss, A., Mugisha, J., Waithaka, M. and Tukahirwa, J. (2013) Factors Influencing the Adoption of Soil Erosion Control Technologies by Farmers along the Slopes of Mt. Elgon in Eastern Uganda. Journal of Sustainable Development, 6, 9-25. https://doi.org/10.5539/jsd.v6n2p9

[33] Senait, R. (2005) Determinants of Choice of Land Management Practices: A Case of Ankober District. Ethiopian Journal of Agricultural Sciences, 18, 53-67.

[34] Haque, M.M., Little, D.C., Barman, B.K. and Wahab, M.A. (2010) The Adoption Process of Rice Fish Based Fish Seed Production in Northwest Bangladesh: An Understanding through Quantitative and Qualitative Investigation. The Journal of Agricultural Extension and Education, 16, 161-177. https://doi.org/10.1080/13892241003651415

[35] Teklewold, H., Kassie, M. and Shiferaw, B. (2012) On the Joint Estimation of Multiple Adoption Decisions: The Case of Sustainable Agricultural Technologies and Practices in Ethiopia. Selected Paper Prepared for Presentation at the International Association of Agricultural Economists (IAAE) Triennial Conference, Foz do Iguaçu.

[36] Chukwu, A.O. and Obi, K.U. (2014) Determinants of Use of Improved Cassava Production Technologies among Smallholder Farmers in Imo State, Nigeria. Asian Journal of Science and Technology, 5, 67-70.

[37] Nkamleu, G.B. and Adesina, A.A. (2000) Determinants of Chemical Input Use in Peri-Urban Lowland Systems: Bivariate Probit Analysis in Cameroon.

[38] Tatlidil, F.F., Boz, I. and Tatlidil, H. (2009) Farmers Perception of Sustainable Agriculture and Its Determinants: A Case Study in Kahramanmaras Province of Turkey. Environment, Development and Sustainability, 11, 1091-1106. https://doi.org/10.1007/s10668-008-9168-x

[39] Haque, M.M., Kabir, M.H. and Nishi, N.A. (2016) Determinants of Rice Farmers' 
Adoption of Integrated Pest Management (IPM) Practices in Bangladesh. Journal of Experimental Agriculture International, 14, 1-6.

[40] Owusu, V., Bakang, J.E.A., Abaidoo, R.C. and Kinane, M.L. (2012) Perception on Untreated Wastewater Irrigation for Vegetable Production in Ghana. Environment, Development and Sustainability, 14, 135-150. https://doi.org/10.1007/s10668-011-9312-x

[41] Mazvimavi, K. and Twomlow, S. (2009) Socioeconomic and Institutional Factors Influencing Adoption of Conservation Farming by Vulnerable Households in Zimbabwe. Agricultural Systems, 101, 20-29.

[42] Mauceri, M., Alwang, J., Norton, G. and Barrera, V. (2005) Adoption of Integrated Pest Management Technologies: A Case Study of Potato Farmers in Carchi, Ecuador. American Agricultural Economics Association Annual Meeting, Providence, 24-27 July 2005.

[43] Kabir, M.H. and Rainis, R. (2015) Do Farmers Not Widely Adopt Environmentally Friendly Technologies? Lesson from Integrated Pest Management (IPM) Modern Applied Science, 9, 208-215. https://doi.org/10.5539/mas.v9n3p208

[44] McNamara, K.T., Wetzstein, M.E. and Douce, G.K. (1991) Factors Affecting Peanut Producer Adoption of Integrated Pest Management. Applied Economics Perspective and Policy, 13, 129-139. https://doi.org/10.2307/1349563

Submit or recommend next manuscript to SCIRP and we will provide best service for you:

Accepting pre-submission inquiries through Email, Facebook, LinkedIn, Twitter, etc. A wide selection of journals (inclusive of 9 subjects, more than 200 journals)

Providing 24-hour high-quality service

User-friendly online submission system

Fair and swift peer-review system

Efficient typesetting and proofreading procedure

Display of the result of downloads and visits, as well as the number of cited articles

Maximum dissemination of your research work

Submit your manuscript at: http://papersubmission.scirp.org/

Or contact jgis@scirp.org 